\title{
Barth on election and the Canons of Dort
}

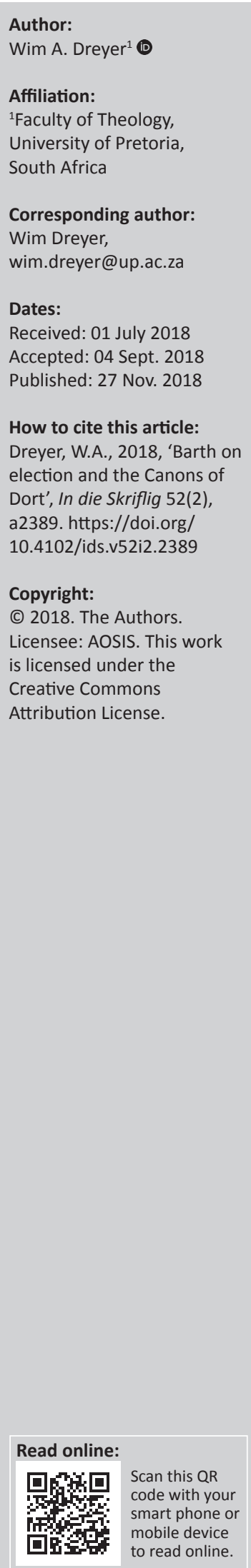

After the Second World War, a renewed interest in the doctrine of election became evident. Several influential and leading theologians published monographs on divine election. One reason for this was the publication of the second part of volume two of Karl Barth's Kirchliche Dogmatik during 1942. Barth regarded the doctrine of election as the heart of the gospel. Fifty years after Barth's death and in the year in which reformed churches all over the world commemorate the Synod of Dort (1618-1619), this contribution reflects on Barth's revisionist understanding of election and his critique of the Canons of Dort.

\section{History and context}

During 2018, 50 years after Barth's death (10 December 1968) and 400 years after the Synod of Dort (1618-1619) it seems appropriate to reflect on Barth's revisionist understanding of election and his critique of the Canons of Dort.

The purpose of this contribution is not to give a complete overview of Barth's doctrine of election. That would be impossible to do in a few pages. The purpose is firstly, to investigate Barth's explicit references to the Canons of Dort in Kirchliche Dogmatik II/2 (KD II/2), and secondly, to make some remarks on the revisionist character of Barth's understanding of election. Barth's use of the Canons of Dort does not seem to attract much scholarly attention. Some historical background are included to create context for the reading of Barth's understanding of election and references to the Canons of Dort.

Many reformed churches will commemorate the Synod of Dort (1618-1619) during its 400-year centenary, but it will not receive the same attention everywhere. For many the Synod of Dort epitomises the reformed tradition and what it means to be reformed (Selderhuis 2015:XV). Even theologians critical of formulations in the Canons of Dort ${ }^{1}$ would agree that the doctrine of election has, at least historically, a very specific place in reformed theology. Karl Barth ([1942] 1957) wrote:

It is a well-known historical fact that more than any other doctrine the doctrine of predestination ${ }^{2}$ stamped itself upon the face of the Reformed Church, or rather of 16th and 17th century theology, thus distinguishing it from others. (p. 36)

Opposing views on election had been the source of much controversy during the long history of especially, the Latin or Western church. The opposing interpretations of election (including original sin, grace, free will, election and rejection) as articulated by Augustine of Hippo in opposition to Pelagius, Martin Luther in opposition to Desiderius Erasmus and John Calvin in opposition to Albert Pighius are well known. A 100 years after Luther posted his 95 theses against the indulgences, the Synod of Dort tried to resolve the opposing interpretations of election as articulated by the Dutch Remonstrants and Contra-Remonstrants by formulating the Canons of Dort. Despite the tremendous effort and dedication of the delegates to the Synod of Dort, it still was not the final word. Often the Canons of Dort were defended fervently; sometimes criticised as contrary to Scripture; sometimes ignored by dissenting theologians and clergy in fear of losing their position in the church. As a result, Herman Bavinck (1928:332), (following Theodor Kaftan) was of the opinion that the doctrine of election received very little attention in modern theology.

1.See Jonker (1994:146-147) for a short overview, specifically his comments on the 1970 decision of the Gereformeerde Kerken Nederland (GKN) which rejected the Canons of Dort's exposition of eternal rejection. The Synod of the Reformed Churches had been influenced by the views of G.C. Berkouwer, for years the leading theologian of the Reformed Churches in the Netherlands and professor of Systematic Theology at the Free University (VU) in Amsterdam. Berkouwer also rejected the idea of parallel decrees of election and rejection. However, following Bavinck, he points out that the Canons of Dort does make a distinction between election and rejection, and that it does not function in the same manner (Berkouwer 1960:177).

2.A sharp distinction between election and predestination should not be made. If a distinction must be made, predestination is the general term for God's sovereign ordaining, while election is the specific term for God's act of choosing or electing people to be his church. In short, predestination could be regarded as a wider category with election a subset of predestination. In Barth's writing, both terms are used often. 
This situation changed after the Second World War. The publication of the second part of volume two of Karl Barth's KD II/2 during 1942, ${ }^{3}$ triggered a renewed debate on election and double predestination (Van der Zanden 1949:7). Barth's understanding of election very quickly exerted great influence, especially in the Netherlands (Graafland 1987:571). Barth spoke of Jesus Christ who is at the same time the electing God, the elected man, the rejected man and the One in which all humanity is elected. It challenged theologians all over the world to rethink the doctrine of election (Heyns 1978:93; Jonker 1989:123; 1994:146; Van der Zanden 1949:8; Van Wyk 2018:1). From a historical perspective, it is clear that Barth's revisionist approach (Janowski 2016:322) to the doctrine of election cannot be ignored when we reflect on the Canons of Dort.

For Barth, the doctrine of election is fundamental to the doctrine of God (Webster 2000:88), and as such, it held a primary place in the architecture of his theology ( $\mathrm{O}^{\prime} \mathrm{Neill}$ 2004:311). McCormack (2000:92) is of the opinion that it should be regarded as Barth's greatest contribution to Christian theology. It also became one of the most controversial features of Barth's theology, because it could be regarded as a corrective on the views of Calvin and classical reformed doctrine (McCormack 2008:1883-1884; Scheuers 2011:161-162). Barth's revisionist approach to the doctrine of election is based upon his fundamental epistemological principle, namely that Jesus Christ is the ground, the centre and the focus of all human speech about God (O’Neill 2004:312).

Barth gave specific attention to the doctrine of election in four different stages of his theological development (see Graafland 1987:508-510). One must consider that, during the period Barth was working on the doctrine of election in preparation of $K D I I / 2$ the German Christian Movement embraced Hitler's agenda of turning Jesus into a nonJewish, Arian Messiah which obviously brought the election of Israel as God's chosen people into question. The extent to which Barth debates the election of Israel as articulated by Paul in Romans 9-11 in KD II/2 shows that it laid heavy on his mind (Barth [1942] 1948:222-226), especially as the extermination of the Jewish population gathered momentum. It is also evident in the way he connects Israel to the Christian church (Barth [1942] 1948:215-226). The continuity and existential unity between Israel and the church in the KD II/2 was nothing new. Barth already articulated these sentiments in 1919 in Der Römerbrief. In his introduction to chapters 9-11, Barth points out that the knowledge of God leads unavoidably to 'Eintreten auf die Not der jetzigen Welt ... Darum ist uns die Not Israels, die Not der Kirche, eine wirkliche und eigene Not' (Barth 1919 [1963]:264). The crisis of Israel and the crisis of the church is one and the same. In terms of election, Israel, church and covenant are intrinsically connected. 3.For the purpose of this study the third edition of Barth's KD il/2 ([1942] 1948) was
used as well as the official English translation, edited by Bromiley and Torrance (Barth [1942] 1957).
During the various stages of his work on the doctrine of election, Barth published his views in four publications which, each on its own, became quite influential. These publications were:

1. The second edition of Der Römerbrief (Barth [1922] 1976) in which Barth drew the basic lines of his Christological understanding of predestination and election. In 1922, his approach appeared to be more theoretical. This was further enunciated in lectures he presented at the University of Göttingen during 1923, especially his lectures on the Canons of Dort (to which we will return later). These lectures were originally published under the title Der Theologie der reformierten Bekenntnisschriften, Vorlesung Göttingen Sommer semester, 1923 (see Barth 2002). ${ }^{4}$

2. During 1936, Barth delivered a series of lectures in Hungary and Romania. These lectures were published in Theologische Existenz Heute under the title Gottes Gnadenwahl (Barth 1936b). The main theme in this publication is 'Es bedeutet Gnade, Gnade zu empfangen - das ist der allgemeine und grundsätzliche Sinn der Prädestinationslehre' - it is grace to receive grace (Barth 1936b:6). Barth maintained a strong pastoral approach in this publication. In a lecture, presented at an international conference on predestination held in Genève in that same year, Barth pointed out that an 'actual' understanding of predestination over and against a 'static' understanding did not really solve the problems intrinsic to the old reformed doctrine of election (see Barth [1942] 1948:207-214; Van der Zanden 1949:17). Barth emphasised the complete freedom of God.

3. This was followed by the KD II/2, first published in 1942, to which we will return later in more detail. Barth's $K D$ $I I / 2$ is nine times the size of Calvin's Institutio Christianae Religionis and twice the size of Aquinas' Summa Theologiae (Lindsay 2004:328). His systematic and extensive exposition of the doctrine of election is to be found in Chapter VII of the KD II/2 and covers more than 500 pages. It is divided in four 'paragraphs' in which Barth addressed the problem of a correct doctrine of the election of grace (par. 32); the election of Jesus Christ (par. 33); the election of the community par. 4); and the election of the individual (par. 35). Writing this section of the KD II/2, Barth experienced moments of despair due to the fact that there had been no precedent to his unique approach to the doctrine of election. In fact, he was at odds with the reformed tradition for which he had a fundamental respect (Webster 2000:88).

4. During 1947, Barth published Die Botschaft der freien Gnade Gottes (1947a). It was reprinted several times in various publications during 1947 and 1948. In this publication, Barth placed the focus on the church and what it means to be church. Barth was convinced that you cannot speak of election without speaking about the church or Israel. It is also in this publication that Barth gave prominence to the formula 'ecclesia semper reformanda' - which became so influential after the Second World War (see Dreyer 2017).

4.For the purpose of this article, the English edition by D.L. Guder and J.J. Guder (Barth 2002) was used. 


\section{Barth and the reformed confessions}

After Barth had been appointed to the chair in Reformed Theology at the University in Göttingen, he often lectured on the history and content of the reformed confessions (see Barth 2002). Barth was confronted by modernist and liberal theologies, and the massive impact it had on the church (Busch 1976:154; 2002:vii). Reformed confessions, and specifically the Canons of Dort, had lost much of their appeal. Since the middle of the 19th century, several reformed churches had, at best, an ambivalent approach towards the confessions. Several reformed churches discarded the Heidelberg Catechism as means of instruction to young people preparing for confirmation. Against this background, Barth's confessional approach should be seen as part of a wider movement of confessional renewal since the late 19th century, evident in the German Lutheran renaissance and 'Young Reformed Movement' with a pronounced anti-liberal stance (Busch 2002:vii-viii).

His confessional approach was not limited to the reformed confessions. Barth also presented lectures on the Credo during 1935 at the University of Utrecht (see Barth 1936a:1). These lectures were reworked and presented during the summer semester of 1946 at the University of Bonn (see Barth 1947b:3).

It was followed by lectures on the Heidelberg Catechism during the summer semester of 1947 also at Bonn (see Barth 1964:15). These lectures were published during 1948 under the title Die christliche Lehre nach dem Heidelberger Catechismus (see Barth 1964). In 1960, his Einfuhrung in den Heidelberger Katechismus appeared in print. It was based on a lecture delivered on the 4th of October 1938, presented to teachers in Switzerland (see Barth 1964:119).

It is clear that Barth had a life-long interest in and appreciation for confessional theology. In the first section of his Göttingen lectures (Barth 2002:1-37), Barth in depth explains the significance and importance of confessions. Despite this, Barth points out that the reformed confessions 'essentially could not have the character of final words ... [or] become a symbol' (Barth 2002:26-27). For instance Barth (2002:27) criticised Abraham Kuyper, who made the past as well as the reformed tradition and confession normative for the present. The only real norm is Scripture. Theologians need to engage critically with reformed theology and doctrine, including the confessions. Barth's own revisionist approach is quite evident in his interpretation of the doctrine of election. KD II/2 not only contains a revision of the traditional reformed doctrine of election, but also presents us with an evolutionary development of his own views in comparison to his earlier works (see Gockel 2006:3-4).

Barth's Der Römerbrief (Barth 1919 [1963]) as well as his Göttingen lectures of 1923 contain some of his earlier views on the doctrine of election (see Gockel 2006:3-4). Barth's extensive knowledge of the history and theology of the reformed confessions are quite apparent from his Göttingen lectures (see Barth 2002:1-37). During July 1923 Barth presented three lectures on the Canons of Dort, under the heading 'The Battle against Modernity' (Barth 2002:206-225). In these lectures he articulated his appreciation for the Canons of Dort, even stating that the 'Canons of Dort are far superior to the Westminster Confession' (Barth 2002:216). For Barth (2002), the Canons of Dort contains the essential reformed faith:

I need not say much by way of explanation of the differences on this point. There are two different worlds that collide with each other here ... on the one hand, the human person is the measure of all things, and on the other, God is. On the one hand, faith as a human act is in the center, and on the other, the divine 'good pleasure' (beneplacitum) out of which come faith and all other good things. On the one hand, a humanly righteous and rational relationship with God, and on the other, God to whom alone all righteousness and reason are ascribed. On the one hand, the human standing in a mild equality with God; on the other, God's mercy as the only thing with which the human stands or falls. Whether one calls what emerges here medieval Semi-Pelagianism or a modern Christianity of feeling and reason, it ends up as the same thing, and it stands in decisive contrast with the Reformation itself. There is no way to deny that what is expressed in the Canons of Dort is the authentic concern of the Reformation. Their case against the Remonstrants is entirely justified and consistent from the perspective of Luther and Calvin. The consequences from the opposed doctrine drawn in the 'rejection of errors' (Rejectio errorum) are also correct. Dort's own doctrine is, as a whole, nothing other than the comprehensive, levelheaded, judicious, thorough expression of what had to be said about the majesty of God, if one were not willing to haggle. With this dogma the Reformed church had raised the banner against the old church some eight or nine decades earlier. With the same dogma it was now setting out the boundaries over against the emerging new church. It is difficult to see what right one might have to call oneself Reformed today if one is not able to engage in the essentials of this thinking. (pp. 214-215)

However, Barth (2002:215-216) was also critical of the Canons of Dort, especially the fact that it placed too much emphasis on the individual. Because of the importance of the individual's salvation, the Canons of Dort planted the seeds of future corruption, of an individualistic and anthropocentric theology. Barth was of the opinion that the turn from God to humanity in reformed theology was implicitly present in the Canons of Dort. As Barth developed his understanding of the doctrine of election, he articulated his view that the traditional reformed doctrine of election with its strong emphasis of the individual believer, correlates with the rise of individualism in Western Europe and Modernity (Gockel 2006:3).

Secondly, Barth was of the opinion that the faith of the individual had become so important that the death of Christ, as the basis of reconciliation, almost becomes redundant. The emphasis on personal faith becomes even more problematic when the 'chosen' actually think they are not only known to God, but also to each other. This could lead to extreme sectarianism (Barth 2002:216-217). This also 
leads to free church fellowship or ecclesial enclaves as happened within modern pietism.

The third early criticism (Barth 2002) on Canons of Dort is the following:

That there is so little said about faith and the forgiveness of sins in Dort, and in contrast so much about what the elect and believers allegedly are and have on the basis of their election, is to me the most problematic point of this otherwise very beautiful confession. (p. 224)

Barth was of the opinion that the inherent qualities (qualitates infusae) which the Canons of Dort ascribes to the elect are reminiscent of Roman Catholic concepts.

These three short examples are enough to show that Barth, from early on, engaged in a positive manner with the confessions, but at the same time, he did not hesitate to criticise aspects he did not agree with. Barth did not merely 'recycle' existing ideas and knowledge, he creatively reshaped and reinterpreted reformed theology and doctrine.

\section{Kirchliche Dogmatik II/2 Introductory remarks}

Barth did not reference the Canons of Dort extensively in $K D$ $I I / 2$. The Canons of Dort are mentioned explicitly only in four sections of KD II/2 (Barth [1942] 1957:17ff.; 67ff.; 111ff.; 327ff.). Numerically, it is almost insignificant in comparison to the more than 500 pages Barth devoted to the doctrine of election. However, it should not be interpreted as if Barth regarded the Canons of Dort as unimportant. As indicated before, he had much appreciation for the work of the Synod of Dort. Even more, it is clear that Barth was mindful of the classic formulations of the reformed doctrine of election. In KD II/2, he continually enters into conversation with Luther, Calvin and other reformed theologians as well as various confessions. Even when he does not mention the Canons of Dort explicitly, it lingers somewhere in the background.

Barth ([1942] 1948:1) begins paragraph 32 of KD II/2 with the statement that the Erwählungslehre ist die Summe des Evangeliums ... [The doctrine of election is the sum of the gospel]. At the heart of the gospel lies the fact that God, in complete freedom, elected to be a God for us. God's decision to be God for us became clearly visible in Jesus Christ. He is at once the electing God and elected man. Predestination is not in the first place about man, but about God who predestined himself to be God for us. The doctrine of election bears witness to the eternal, free and unchanging grace of God.

After this opening statement, Barth gives an overview of the history of the doctrine of election (Barth [1942] 1948:12-24). He emphasises that most exponents of the doctrine (including Augustine, Luther and Calvin) understood the doctrine of election in a positive manner. Barth ([1942] 1948:14) states categorically that this positive approach to the doctrine of election must be maintained in all circumstances. Barth points out that the Old Testament presents the election of Israel in a positive light. In the New Testament a passage such as Romans 9-11 (which is so central in Barth's thinking since the first edition of Der Römerbrief in 1919), despite all the difficult contradictions, bear witness to the 'Divine Yes' to Israel.

Barth's references to Luther and Calvin (and others) must be read with caution, especially in the light of their changing views on predestination and their almost hesitant approach towards the mystery of divine election. It is not so easy to pinpoint Luther's or Calvin's views on election and predestination. Luther, for instance in his altercation with Erasmus, asserted a double predestination (see Graafland 1987:9). Interestingly enough, that approach to predestination disappeared from Luther's writings in later years. Luther ([1525] 2006:404) was of the opinion 'Quae supra nos, nihil ad nos' [What is above us, is none of our business]. In Calvin's case, the way he repositioned the doctrine of election in various editions of the Institutes is a clear indication of how he developed his interpretation of the doctrine (see Graafland 1987:5-46).

From the outset, Barth ([1942] 1948:1) explains that the only way we could speak about election, is on the basis of Holy Scripture. The starting point must always be what God reveals about himself, although we also listen gratefully to the old and new voices coming from the church. However, the very first voice that comes to us and to which theologians must listen carefully, is that of Jesus Christ. Any attempt to speak about God without listening to the voice of Jesus, ends up in some arbitrary conception of God which says more about our understanding of man than God (Barth [1942] 1948:2). This implies that we cannot speak about the doctrine of election without speaking about Jesus Christ.

In this, Barth follows Luther's distinction between Deus absconditus and Deus revelatus which not only forms an essential part of Luther's understanding of predestination, but his whole theology (see Van Wyk 2018:3). Luther, in his criticism of the philosophical approach of Scholasticism, emphasised that we can only speak about the 'revealed God'. This is especially true of the doctrine of election.

\section{The foundation of a correct doctrine of election (par. 32)}

The first passage (Barth [1942] 1957:17ff.), which mentions the Canons of Dort, refers to the definition of election as articulated in Article I/7 of the Canons of Dort (see text in Bakhuizen van den Brink 1940:226). ${ }^{5}$ Barth [1942] 1957:17) makes a very short but positive remark on $\mathrm{I} / 7$, by stating that the definition (which he quotes in Latin) did not include divine reprobation as an autonomous truth. Rather, the Canons of Dort speaks in a positive way about election as having the character of evangelical proclamation. Article 1/7 defines election as follows:

5. For the text of the Canons of Dort, I made use of Bakhuizen van den Brink's edition (1940:218-287) of the Latin and Dutch texts. 
Election is the unchangeable purpose of God whereby, before the foundation of the world, out of the whole human race, which had fallen by its own fault out of its original integrity into sin and perdition, He has, according to the sovereign good pleasure of His will, out of mere grace, chosen in Christ to salvation a definite number of specific persons, neither better nor more worthy than others, but involved together with them in a common misery. He has also from eternity appointed Christ to be the Mediator and Head of all the elect and the foundation of salvation and thus He decreed to give to Christ those who were to be saved, and effectually to call and draw them into His communion through His Word and Spirit. He decreed to give them true faith in Him, to justify them, to sanctify them, and, after having powerfully kept them in the fellowship of His Son, finally to glorify them, for the demonstration of His mercy and the praise of the riches of His glorious grace. As it is written: 'God chose us in Christ, before the foundation of the world, that we should be holy and blameless before Him. He destined us in love to be His sons through Jesus Christ, according to the purpose of His will, to the praise of His glorious grace which $\mathrm{He}$ freely bestowed on us in the Beloved (Eph 1:4-6)'. And elsewhere, 'those whom He predestined He also called; and those whom $\mathrm{He}$ called $\mathrm{He}$ also justified; and those whom He justified $\mathrm{He}$ also glorified' (Rm 8:30). (p. 18)

After rejecting human experience (Schleiermacher) or the private relationship between God and an individual as a foundation for the doctrine of election, Barth ([1942] 1957:38-43) also debates the question whether God's omnipotence should be considered as the foundation of the doctrine of election (p. 45ff.). Barth ([1942] 1957:45-46) disagrees with Thomas Aquinas and Bonaventura on the issue of God's irresistible omnipotence when it comes to election, because that leads to a doctrina in abstracto. The over-emphasis of God's omnipotence results in predestination becoming a deterministic and absolute decree, in fact a decretum horrendum.

Barth ([1942] 1957:48-59) is very clear that we can only speak about election after we had listened carefully to Scripture. And now the critical point:

If we listen to what Scripture says concerning man, then the point where our attention and thoughts are allowed to rest there is revealed an elect man, the elect man, and united in Him and represented by Him an elect people. (p. 58)

Jesus Christ is the elected man. His people are elected $\dot{\varepsilon} v$ av่ $\tau \tilde{\varphi}$ in him. This is clearly not a modernist or individualistic understanding of election. Election is not, in the first place, about the individual's personal religious experience or relation with God, but about Christ and his people.

The second passage in which Barth mentions the Canons of Dort explicitly (Barth [1942] 1957:67ff.) is also part of the foundation of the doctrine of election. Central to Barth's argument, to which he returns in almost every section, is Ephesians 1:3-10 (see Barth [1942] 1957:60ff.). He follows the Canons of Dort which quotes Ephesians 1:4-6 in I/7 as part of the Synod's definition of election (see above). Both the Canons of Dort and Barth used this text as basis for their reflections on the doctrine of election. Van der Zanden (1949:8, 32) agrees with Barth ([1942] 1957:60) that the doctrine of election had been determined by the interpretation of Ephesians 1:4. He says: 'Op het verstaan hiervan komt het in de leer der verkiezing ten volle aan.' The other passage to which Barth often returned in his reflection on election, is of course Romans 9-11.

The Greek text of Ephesians 1:3-10 reads as follows (quoted here to follow Barth who works with the original Greek text):

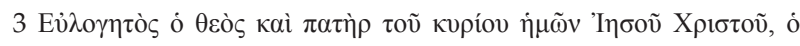

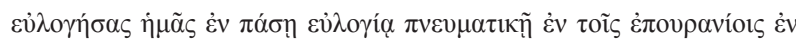

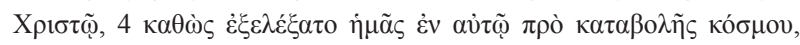

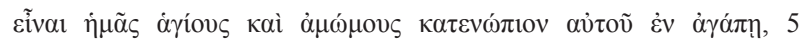

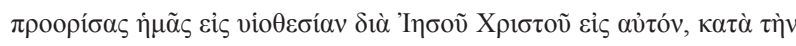

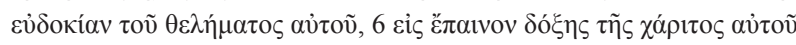

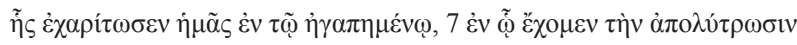

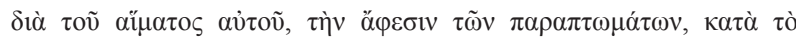

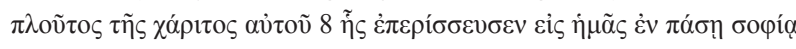

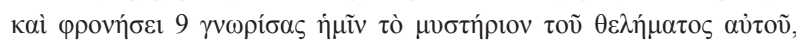

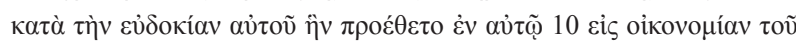

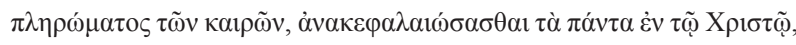

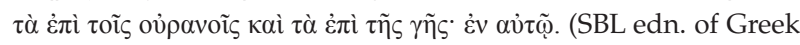
New Testament)

[3 Praise be to the God and Father of our Lord Jesus Christ, who has blessed us in the heavenly realms with every spiritual blessing in Christ. 4 For he chose us in him before the creation of the world to be holy and blameless in his sight. In love 5 he predestined us for adoption to sonship through Jesus Christ, in accordance with his pleasure and will -6 to the praise of his glorious grace, which he has freely given us in the One he loves. 7 In him we have redemption through his blood, the forgiveness of sins, in accordance with the riches of God's grace 8 that he lavished on us. With all wisdom and understanding, 9 he made known to us the mystery of his will according to his good pleasure, which he purposed in Christ, 10 to be put into effect when the times reach their fulfilment - to bring unity to all things in heaven and on earth under Christ.] (transl. New International Version)

After extensive discussion (Barth [1942] 1957:61-65) of

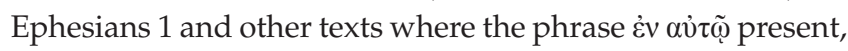
Barth reaches the conclusion that reformed theology was well aware of the fact that Christ is the centre of all theology and Christian faith. Luther's 'was Christum treibet' was not unique to the Lutheran theology. Augustine gave a Christological explanation of predestination (Barth [1942] 1957:60). This was followed by Luther as well as Calvin. But, Barth ([1942] 1957:63) maintains that there is something missing in both Lutheran and Calvinistic theology in terms of their Christological interpretation of election. Christ is not seen as the subject of election, but as the instrument of God's dealings with man. The Christological centre gave way to the secret electio Patris and election as a decretum absolutum (Barth [1942] 1957:67).

It was to this that Arminius responded and which led to the Synod of Dort. Arminius and his followers objected to the Calvinistic doctrine of the decretum absolutum (Barth [1942] 1957:67). To Barth's opinion, the weakness of the Arminian argument was not the opposition to the decretum absolutum, 
but that man again became the norm. Man's conception of what is right, rational and worthy becomes the basis of doctrine. In effect, the Remonstrants denied that there was any divine decision at all (Barth [1942] 1957:68). It all comes down to man's decisions and faith.

Barth agrees fully with the Synod of Dort's rejection of the Arminian and Remonstrant views, but criticises the Synod for not coming to grips with the radical implications of what the Remonstrants were proposing (Barth [1942] 1957:68). Even more, the Synod did not fully appreciate the implications of Ephesians 1 and the importance of what it means to be elected in Christ.

\section{The election of Jesus Christ}

The third section where Barth ([1942] 1957:111ff.) mentions the Canons of Dort explicitly, is in paragraph 33 where his Christological interpretation of the doctrine of election is very prominent (p. 94). The heading of paragraph 33 is 'The election of Jesus Christ'.

In this section he continues his discussion of the central question: What does it means to be elected ' $\varepsilon$ v $\alpha$ vo $\tau \tilde{\omega}^{\prime}$ ', to be

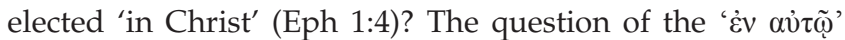
cannot be bypassed easily by referring to it as the 'mystery of God' (Barth [1942] 1957:111). There are no easy answers.

Through history, Christ was often presented as the first of the elect according to his human nature. Thomas Aquinas was quite influential to establish this line of argumentation, although (as Barth explains) Aquinas did not realise that it

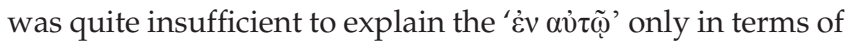
the elected man. We cannot limit Christ to be the elected man. If we take the Word of God seriously, Christ is also the electing God.

This is also the essence of Barth's criticism of Calvin. In some passages, Barth ([1942] 1957:111-118; Graafland 1987:524525) presents us with severe criticism of both Calvin and the Canons of Dort. According to Barth ([1942] 1957:111), all the features of Calvin's approach to the doctrine of election, which creates doubt in our minds, relate to the one fact that he dislocated the eternal decree of election from Jesus Christ who is not only the elected man, but also the electing God. The fact that Calvin did not think of Christ as the electing God, forms the basis of Barth's objection against Calvin's understanding of predestination. The electing God of Calvin is a Deus nudus absconditus, a God hidden from humanity.

It is the same criticism Barth ([1942] 1957:111) levels against the Canons of Dort. The Synod merely repeated, only with harsher words, the unsatisfactorily answer to the question of 'ยेv $\alpha \dot{\tau} \tau \tilde{\varphi}^{\prime}$. It was even worse with the Arminians who (according to Barth) introduced a new form of Pelagianism from which a Neo-Protestantism would develop with strong humanistic tendencies in which the decisions and acts of people take centre stage. During the 17th century, theologians could not find a way to escape this dilemma.
Barth ([1942] 1957:112) agrees with the Synod on the principle of causa efficiens impulsiva electionis, namely that which 'motivates the will of God is not to be sought outside God Himself, but solely in His free good pleasure'. Election, as such, is grace, given freely by God. Election has its origins in God self, nowhere else. It can neither be found in a created reality nor in the will of a human being - not even in faith or prayer. Even more - the meritum Christi is not the cause or basis of election, but the result of election.

It is also at this point that Barth becomes quite severe in his criticism of the Canons of Dort. Barth [1942] 1957:113) was of the opinion that the zeal to 'protect' the mystery of God's free will and divine decree of election, prevented the Synod to discern in a proper manner that faith in Christ needs to complement election. The inevitable result was that in the 'shadow such a Christless doctrine of predestination' a reformed mysticism and secular ascetism would flourish. The decretum absolutum led unavoidably to pietism, moralism and mysticism.

Barth ([1942] 1957:113-114) comes to the conclusion that the reformed churches had no cause to pride themselves on a 'false start' (i.e. the decretum absolutum). We should recognise it as a false start (falschen Ansatz) and this error should not be continued (Barth [1942] 1948:122). The decretum absolutum must be 'replaced by the Word of God which was in the beginning with God'. Coccejus made such an attempt with a theology based on the covenant of grace. Coccejus was convinced that firstly, the decree of election is identical to salvation; secondly, the decree of salvation relates primarily to the mission and people of the Son; and thirdly, the Son participated in the decree of election as did the Father and Holy Spirit (Barth [1942] 1957:115). Barth agrees with Coccejus that these three points set aside the decretum absolutum.

The first assertion then, is that Jesus Christ is the elected man, but at the same time the electing God. There is no such thing as a decretum absolutum apart from the will of Jesus Christ (Barth [1942] 1957:113). Christ reveals to us our own election as an election ' $\varepsilon \dot{v} \alpha v ่ \tau \tilde{\omega}$ ', an election by him which he willed with the Father and Holy Spirit. He is the one who elects us. Barth ([1942] 1957) concludes with an interpretation of Ephesians 4:1:

'In Him' does not simply mean with Him, together with Him, in His company. Nor does it mean only through Him, by means of that which He as elected man can be and do for them. 'In Him' means in His person, in His will, in His own divine choice, in the basic decision of God which He fulfils over against every man. What singles Him out from the rest of the elect, and yet also, and for the first time, unites Him with them, is the fact that as the elected man He is also the electing God, electing them in His own humanity. (pp. 116-117)

And so they are elect 'in Him'.

Of course, one could question Barth's 'dogmatic' exegesis of Ephesians 1 as often happened since the publication of the 
first edition of Der Römerbrief. In the preface to the third edition of Der Römerbrief, he reacts laconically to the criticism of his dogmatic interpretation of Scripture and lack of attention to historical-critical questions. He (Barth [1922] 1976:16) writes, 'the strangest episode in the history of the book since the appearance of the second edition has been its friendly reception by Bultmann and its equally friendly rejection by Schlatter'.

However, it is quite clear that this interpretation of Ephesians 1 assisted Barth to find a satisfactorily solution to the questions of the decretum absolutum and the meaning of an election ' $\varepsilon \dot{\varepsilon} \nu \alpha \jmath \tau \tilde{\omega}$ '.

\section{The election of the individual}

The fourth reference to the Canons of Dort is to be found in paragraph 35 of KD II/2 where Barth ([1942] 1957:306ff.) examines the election of the individual. This follows paragraph 34 where Barth discussed the election of the community of Gods people - both Israel and the church.

In Christian theology, the individual had always been important. Each human being may live as an authentic and free individual in the presence of God (Van Niftrik 1948:172). The autobiographical Cofessiones of Augustine, the father of the classic doctrine of predestination, is a prime example of the individual soul struggling with the question of salvation (Barth [1942] 1957:307). Traditionally, theologians started with the election of the individual. Barth breaks intentionally with this tradition (Barth [1942] 1957:308) by placing the election of the individual at the end of the discussion as the last question to be answered and not the first. Barth ([1942] 1957) begins paragraph 35 with a customary introductory remark where he points out that:

The man who is isolated over against God is as such rejected by God. But to be this man can only by the godless man's choice. The witness of the community of God to every individual man consists in this: That the choice of the godless man is void; that he belongs eternally to Jesus Christ and therefore is not rejected, but elected by God in Jesus Christ; that the rejection which he deserves on account of his perverse choice is borne and cancelled by Jesus Christ; and that he is appointed to eternal life with God on the basis of the righteous, divine decision ... (p. 306)

After discussing various concepts of what an individual is and how it affected the doctrine of election (Barth ([1942] 1957:309-326) comes to the question of individual faith (p. 326) by saying that faith:

rests on Jesus Christ as the promise of divine compassion towards the ungodly, and it does so as a work and gift of the Holy Spirit. Faith is the opening of man for God as brought about by God Himself. In faith man is the new subject which can no longer compete with God but can only live by Him and with Him and in conformity with Him - torn away from godlessness by His grace and set in this different status, the status of the knowledge of God, of love for Him, of obedience and trust. (p. 327)

Barth concludes that it is correct that election of the individual becomes visible in faith, for it is the grace of God which awakens faith ([1942] 1957:327). But now the question: How can the grace of God mean that one individual is elected and the other is passed over, especially if all of humanity is objectively called to believe (elected) by the same promise which is Jesus Christ? Consequently, we cannot deduce from the unbelief of an individual that he or she has not been elected. To substantiate this line of argumentation, Barth ([1942] 1957:327) refers to Calvin's Commentary on I Corinthians and Institutes where he speaks of a iudicum caritatis according to which there also a vocatio ad salutem and that we should commend them to God in our prayers.

Barth follows this argument with a very short quote from the Canons of Dort (III-IV, 15) where it is also said that the 'heart of others' is unknown to us and (as with Calvin) we need to pray for everyone. The believers may not, under any circumstance, exalt themselves over and against those who do not believe. He (Barth [1942] 1957:327-328) also finds support for this in the writing of Bullinger and in the Cofessio Sigismundi.

The elected individuals are what they are because of the actual relationship of God to them and their actual relationship to God. Election has its basis in God alone, through the election of Jesus Christ and by means of his community (Barth [1942] 1957:341). The individual believer is always an individual in relation to the community (Barth [1942] 1957:315-316). The individual believer is a believer because of the relationship with Christ (being 'in Christ') and being part of his community.

The fourth reference to the Canons of Dort does not contain anything controversial per se, although many (including Emile Brunner) criticised Barth severely for opening the door to universalism that all humanity is elected and saved in and through Christ. Maybe we could conclude with a quote from paragraph 35 (Barth [1942] 1957) where Barth explains the difference between the elect and the other: ${ }^{6}$

This, then, is how the elect and the others differ from one another: The former by witnessing in their lives to the truth, the latter by lying against the same truth. It ought to be clear to this extent they belong together. The elect are obviously to be found in the sphere of the divine election of grace, in the hand of the one God, under the reign whose beginning and principle are called Jesus Christ. But the others are also to be found there. The former are there in obedience, the latter in disobedience; the former as free children of the household, the latter as forced and refractory slaves; the former under God's blessing, the latter under His curse ... Believers 'are' the elect in this service so far as they bear witness to the truth, that is, to the elect man, Jesus Christ, and manifest and reproduce and reflect the life of this one Elect. The godless 'are' the rejected in the same service so as by their false witness to man's rejection they manifest and reproduce and reflect the death of the one Rejected, Jesus Christ. Because this One is the Elect and the Rejected, He is attested by both - the Lord and Head of both the elect and also of the rejected. (pp. 346-347)

6.Note: Not the 'non-elect' or 'rejected', but the 'other' 
It is clear from this passage that Barth stays within the traditional pattern of a double predestination (Graafland 1987:514; Van der Zanden 1949:29). The rejection is, however, located in Jesus Christ. There is indeed something like rejection and eternal death, but the One that is rejected is Christ. Those who do not serve Christ in obedience, do so on their own accord. With this approach, Barth made an attempt to ameliorate the thorny issue of divine rejection.

Barth was very much aware that there is a real 'danger' (Webster 2000:89) if election would be based on a 'concept of God as omnipotent Will, governing and irresistibly directing each and every creature according to his own law' (Barth [1942] 1957:44). That would lead to a God in abstracto, a theoretical God which could become a fiction of the human mind undetermined by God's self-revelation through the Word. Barth rejected the notion of an abstract or absolute decree through which God predestined some people to be saved and some to be damned. Barth's revisionist approach to election and rejection (as articulated in the passage above) into a message of hope for all humanity.

\section{Conclusion}

According to Barth, election is not about an abstract decree, humanity in general, the idea of a 'human race' or even a small or large number of individuals who are the elect. It is about a relationship which exists between 'God and the one man Jesus and the people represented in Him' (Barth [1942] 1957:8). One cannot 'believe' an eternal decree, but a doctrine of election founded in the (living) Word of God, must be believed (Van Niftrik 1948:158). It is about God's fundamental decision to be God, to be a God for us (Webster 2000:90).

It is clear that Barth's approach to and interpretation of the doctrine of election constitutes a significant revision of the traditional reformed doctrine of election, especially as articulated in the Canons of Dort. Barth, himself, was deeply convinced that his approach to the doctrine of election was not merely an evolutionary progression, but radically new (Graafland 1987:520). Barth departed from the traditional doctrine of election by placing the emphasis on God's revelation and election in Christ, contrary to the traditional emphasis of God's eternal decree (Jonker 1989:121). Fundamental to this new approach is Barth's very specific and unusual Christocentric foundation of the doctrine of election which is encapsulated in his interpretation of election 'in Christ' (Eph 1:4) as well as Christ being the electing God and elected man. In doing so, Barth departed in a fundamental way from the scholastic tendencies of Dort.

On the other hand, contrary to Calvin, Barth gave the doctrine of election a central place in his theology, as did the reformed orthodoxy and the Canons of Dort. (Jonker 1989:121). Even so, he chooses (contrary to Dort) for a supralapsarian position, because Christ is present in divine election even before the fall (Jonker 1989:122). Many theologians in the Lutheran, Reformed and Roman Catholic traditions, with more or less enthusiasm, followed Barth in this approach.
Barth's theology (including the doctrine of election) is fundamentally Christocentric (Cortez 2007:1; Graafland 1987:510). Christ is the electing God, and at the same time, the elected man (Barth [1942] 1957:147). Election in Christ is not just about the individual's salvation, but about the calling of his people to participate in the kingdom of God. With this, Barth made it possible to find joy in the doctrine of election.

\section{Acknowledgements Competing interests}

The author declares that he has no financial or personal relationships which may have inappropriately influenced him in writing this article.

\section{References}

Bakhuizen van den Brink, J.N., 1940, De Nederlandsche Belijdenisschriften Vergelijkende Teksten, Uitgeversmaatschappij Holland, Amsterdam.

Barth, K., [1919] 1963, Der Römerbrief, EVZ-Verlag, Zürich.

Barth, K., [1922] 1976, Epistle to the Romans, transl. E.C. Hoskyns, Oxford University Press, London.

Barth, K., 1936a, Crede: Die Hauptprobleme der Dogmatik dargestellt im Anschluss an das Apostolische Glaubensbekenntnis, Chr. Kaizer Verlag, München.

Barth, K., 1936b, 'Gottes Gnadenwahl', in Theologische Existenz Heute 47, Chr. Kaizer Verlag, München.

Barth, K., [1942] 1948, Kirchliche Dogmatik II/2, Evangelischer Verlag A.G., Zollikon (Dritte Auflage).

Barth, K., [1942] 1957, Church Dogmatics vol. 2, part 2, G.W. Bromiley \& T.F. Torrance (eds.), T.T. Clarke, Edinburgh.

Barth, K., 1947a, 'Die Botschaft von der freien Gnade Gottes', in K.G. Steck \& G. Eichholz (eds.), Theologischen Existenz heute Heft 9, pp. 24-37, Chr. Kaizer Verlag, München.

Barth, K., 1947b, Dogmatik im Grundriss, Evangelischer Verlag A.G., Zollikon

Barth, K., 1964, The Heidelberg Catechism for today, transl. S.C. Guthrie, John Knox Press, Richmond, VA

Barth, K., 2002, The theology of the reformed confessions 1923, transl. and annotated by D.L. Guder \& J.J. Guder, Westminster John Knox Press, Louisville.

Bavinck, H., 1928, Gereformeerde Dogmatiek II, J.H. Kok, Kampen.

Berkouwer, G.C., 1960, Divine election, transl. H. Bekker, Eerdmans, Grand Rapids, MI. Busch, E., 1976, Karl Barth: His life from letters and biographical texts, transl. J. Bowden, SCM Press Ltd., London.

Busch, E., 2002, 'Preface', in K. Barth (ed.), The theology of the reformed confessions 1923 , pp. vii-x, transl. and annotated by D.L. Guder \& J.J. Guder, Westminster John Knox Press, Louisville.

Cortez, M., 2007, 'What does it mean to call Karl Barth a "Christocentric" theologian?', Scottish Journal of Theology 60(2), 1-17. https://doi.org/10.1017/S00369306 0700316X

Dreyer, W.A., 2017, 'Calvin, Van Lodenstein and Barth: Three perspectives on the necessity of church reformation', in Nadenke oor 500 jaar se Reformatoriese teologie, HTS Theological Studies/Teologiese Studies 73(5 Suppl. 11), a4508. https://doi.org/10.4102/hts.v73i5.4508

Gockel, M., 2006, Barth and Schleiermacher on the doctrine of election: A systematictheological comparison, Oxford University Press, Oxford.

Graafland, C., 1987, Van Calvijn tot Barth: oorsprong en ontwikkeling van de leer der verkiezing in het Gereformeerd Protestantisme, 's-Gravenhage, Boekencentrum.

Heyns, J.A., 1978, Dogmatiek, NG Kerkboekhandel, Pretoria.

Janowski, J.C., 2016, 'Gnadenwahl', in M. Beintker (ed.), Barth Handbuch, pp. 321-328, Mohr Siebeck, Tübingen.

Jonker, W.D., 1989, Uit vrye guns alleen: Oor uitverkiesing en verbond, NG Kerkboekhandel, Pretoria.

Jonker, W.D., 1994, Bevrydende waarheid: Die karakter van die gereformeerde belydenis, Hugenote Uitgewers, Wellington.

Lindsay, M., 2004, 'Barth', in G. Jones (ed.), The Blackwell companion to modern theology, pp. 327-342, Blackwell Publishing Ltd., Oxford.

Luther, M., [1525] 2006, 'De servo arbitrio', in W. Härle (Hrsg.), Martin Luther: Lateinisch-Deutsche Studienausgabe, Bnd 1, Der Mensch vor Gott, pp. 219-661, Evangelische Verlaganstalt, Leipzig.

McCormack, B.L., 2000, 'Grace and being: The role of God's gracious election in Karl Barth's theological ontology', in J. Webster (ed.), The Cambridge companion to Karl Barth, pp. 92-115, CUP, Cambridge.

McCormack, B.L., 2008, Orthodox and modern: Studies in the theology of Karl Barth, Baker Academic, Grand Rapids, MI. 
O’Neill, M., 2004, 'Karl Barth's doctrine of election', Evangelical Quarterly 76(4) 311-326

Scheuers, T., 2011, 'An evaluation of some aspects of Karl Barth's doctrine of election' MATJ 22, 161-173.

Selderhuis, H., 2015, 'Introduction to the Synod of Dort (1618-1619)', in D. Sinnema, C. Moser \& H.J. Selderhuis (eds.), Acta et Documenta Synodi Nationalis Dordrechtanae (1618-1619), Vandenhoeck \& Ruprecht GmbH \& Co., Göttingen.
Van der Zanden, L., 1949, Praedestinati: Onze Verkiezing in Christus, J.H. Kok N.V. Kampen.

Van Niftrik, G.C., 1948, Een beroerder Israels, G.F. Callenbach N.V. Uitgever, Nijkerk.

Van Wyk, I.W.C., 2018, 'Luther and Calvin on predestination: A comparison', In die Skriflig 52(2), a2342. https://doi.org/10.4102/ids.v52i2.2342

Webster, J., 2000, Barth, Continuum, London. 